\title{
PENGGUNAAN LIMBAH BATA MERAH SEBAGAI TAMBAHAN SEMEN DALAM PEMBUATAN PAVING BLOCK
}

\author{
Debora Hutagaol ${ }^{1}$, Ronald Butar-Butar ${ }^{2}$ \\ ${ }^{1}$ Alumni Program Studi Diploma III Teknik Sipil, Fakultas Teknik UNIMED \\ ${ }^{2}$ Dosen Pengajar Jurusan Pendidikan Teknik Bangunan, Fakultas Teknik UNIMED \\ (rbutarbutar23@gmail.com)
}

\begin{abstract}
ABSTRAK
Limbah bata merah dipilih sebagai material ramah lingkungan sebagai tambahan semen dalam pembuatan paving block sehingga perlu diteliti daya serap dan kuat tekannya. Pada penelitian ini menggunakan variabel bebas variasi perbandingan semen portland dan limbah bata merah sebesar $100 \%-0 \%, 70 \%-30 \%, 50 \%-50 \%, 30 \%-70 \%$ dan $0 \%-100 \%$ pada campuran mortar. Pada penelitian ini menunjukkan bahwa daya serap paving block tinggi apabila semen portland dicampur dengan limbah bata merah dengan perbandingan 30\%:70\% dan kuat tekannya rendah apabila semen dicampur dengan limbah bata merah.
\end{abstract}

Kata Kunci : Kuat Tekan, Paving Block, Penyerapan Air, Serbuk Bata Merah

\section{ABSTRACT}

Waste redbrick been as environmentally friendly materials as additional cement in the manufacture of paving blocks so it is necessary to study the absorption and compressive strength. In this study, using the independent variable ratio variation of portland cement and brick waste by $100 \%-0 \%, 70 \%-30 \%, 50 \%-50 \%, 30 \%-70 \%$ and $0 \%-100 \%$ in the mix mortar. In this study showed that high absorption of paving blocks where portland cement is mixed with the waste of red brick with a ratio of 30\%: $70 \%$ and lower compressive strength when cement is mixed with the waste of red brick.

Keywords: Compressive Strength, Paving Block, Powdered Red Brick, Water Absorption

\section{Pendahuluan}

Dalam dunia Teknik Sipil yang semakin berkembang ini, menyebabkan meningkatnya pembangunan fisik di Indonesia. Salah satunya pada bidang konstruksi. Semakin banyak inovasi-inovasi baru dalam bidang ini, terutama alternatif bahan perkerasan jalan.
Perkerasan jalan pada umumnya menggunakan aspal, saat ini sering terlihat perkerasan jalan dengan media selain aspal, yaitu paving block.

Paving block sudah dikenal luas oleh masyarakat, hal ini karena paving block merupakan konstruksi yang ramah lingkungan dimana paving block sangat baik dalam 
membantu konservasi air tanah, pelaksanaannya yang lebih cepat, mudah dalam pemasangan dan pemeliharaan, memiliki aneka ragam bentuk yang menambah nilai estetika, serta harganya yang dapat dijangkau.

Bahan lain yang bisa digunakan sebagai bahan tambahan semen maupun beton yaitu limbah bata merah yang terbuat dari tanah liat atau lempung yang dibentuk dan dibakar dalam waktu tertentu kemudian dihancurkan.

Agar penelitian ini lebih terarah, terfokus, dan tidak meluas, penulis membatasi penelitian ini pada teknik pembuatan Paving Block, perbandingan daya serap paving block, daya tekan paving block.

Tujuan dari penelitian ini adalah untuk mengetahui teknik pembuatan, untuk mengetahui perbandingan daya serap, dan untuk mengetahui daya tekan paving block.

\section{Kajian Teori}

\subsection{Pengertian Umum}

Paving block adalah komposisi bahan bangunan yang terbuat dari campuran semen portland atau bahan pengikat hidrolis, air, dan agregat halus dengan atau tanpa bahan tambahan lainnya yang tidak mengurangi mutu dari pada beton tersebut (SK.SNI S-041989).

Dengan adanya penyerapan air pada selasela paving block maka akan membantu mengurangi jumlah air yang berada di jalan karena selain air dapat mengalir ke saluran drainase jalan, air juga dapat menyerap ke paving block dan akan meneruskan ke dalam tanah.

\subsection{Karakteristik Paving Block}

Beberapa hal yang perlu diperhatikan dalam menentukan mutu paving block yang memenuhi persyaratan SNI 03-0691-1996 adalah sebagai berikut :

\section{a. Sifat Tampak}

Paving block memiliki bentuk yang sempurna, tidak boleh mengalami retak-retak atau pun cacat, serta bagian sudut dan rusuknya tidak mudah direpihkan dengan kekuatan tangan.

b. Bentuk dan Ukuran

Dalam hal ini bentuk dan ukuran paving block untuk lantai bergantung dari persetujuan antara pemakai dan produsen.

\subsection{Klasifikasi Paving Block}

Berdasarkan SK SNI T-04-1990-F, klasifikasi paving block antara lain:

a. Bentuk paving block secara garis besar terbagi atas dua macam, yaitu : (a) paving block bentuk segi empat, (b) paving block bentuk segi banyak.

b. Klasifikasi berdasarkan ketebalan ada tiga macam dan dapat disesuaikan dengan kebutuhan sebagai berikut : (a) Paving block dengan ketebalan $60 \mathrm{~mm}$, diperuntukkan bagi beban lalu lintas ringan yang frekuensinya terbatas pada pejalan kaki dan kadang-kadang sedang, (b) Paving block dengan ketebalan $80 \mathrm{~mm}$, diperuntukan bagi beban lalu lintas sedang yang frekuensinya terbatas pada pick up, truck, dan bus, (c) Paving block dengan ketebalan $100 \mathrm{~mm}$, diperuntukkan bagi beban lalu lintas berat seperti: crane, loader, dan alat berat lainnya. Paving block dengan ketebalan $100 \mathrm{~mm}$ ini sering dipergunakan di kawasan indrustri dan pelabuhan.

c. Klasifikasi berdasarkan warna. Selain bentuk yang beragam paving block juga memiliki warna, dimana dapat menampakkan keindahan juga digunakan sebagai pembatas seperti pada tempat parkir, tali air dan lain-lain. Warna paving block yang ada di pasaran adalah merah, hitam dan abu-abu.

\subsection{Keuntungan Paving Block}

Adapun keuntungan dari penggunaan paving block (Dharmawansyah, 2007) adalah sebagai berikut:

a. Dalam pelaksanaan mudah.

b. Dapat diproduksi secara massal

c. Tahan terhadap beban vertikal dan horizontal yang disebabkan oleh rem atau kecepatan kendaraan berat.

d. Adanya pori-pori pada paving block dapat meminimalisasi aliran permukaan dan memperbanyak infiltrasi dalam tanah.

e. Pada saat pengerjaan tidak menimbulkan kebisingan dan gangguan debu.

f. Mempunyai nilai estetika yang unik terutama jika didesain dengan bentuk dan warna yang indah.

\subsection{Metode Pembuatan Paving Block}

Cara pembuatan paving block dapat dilakukan dengan cara metode konvensional. 
Metode ini adalah metode yang paling banyak digunakan oleh masyarakat dan lebih dikenal dengan metode gablokan. Pembuatan paving block cara konvensional dilakukan dengan menggunakan alat gablokan dengan beban pemadatan yang berpengaruh terhadap tenaga orang yang mengerjakan.

\subsection{Karakteristik Pengujian Paving}

Paving block yang telah dibuat dari campuran semen, pasir, limbah bata merah dan air yang telah jadi akan di keringkan. Kemudian akan dilakukan pengujian paving block yang meliputi : daya serap dan kuat tekan.

Pengujian daya serap dapat dilakukan dengan cara:

a. Rendam benda uji dalam air hingga jenuh selama 24 jam, kemudian timbang beratnya dengan keadaan basah.

b. Keringkan dengan oven selama 24 jam pada suhu $90^{\circ} \mathrm{C}$, kemudian timbang dalam keadaan kering oven.

Dengan rumus sebagai berikut :

$$
\mathrm{WA}=\frac{M J-M k}{M k} \times 100 \%
$$

Dimana :

WA $=$ Water Absorption (\%)

Mk = Massa benda di udara/ kering (gr)

$\mathrm{Mj}=$ Massa benda dalam kondisi saturasi jenuh/ basah (gr)

Kuat tekan beton didasarkan pada umur 28 hari. Pengujian benda uji pada penelitian ini hanya dilakukan saat beton mencapai umur 7 hari, dikarenakan waktu yang tidak mendukung untuk benda uji 28 hari. Pada pengujian kuat tekan, digunakan cetakan kubus dengan ukuran $5 \times 5 \mathrm{~cm}$.

Kuat tekan paving block dipengaruhi oleh beberapa faktor, antara lain :

a. Jenis dan kualitas dari semen, pasir dan bahan penambah lainnya.

b. Perbandingan jumlah semen dengan pasir.

c. Perbandingan berat air dengan semen.

d. Cara pembuatannya berdasarkan seberapa besar pemadatan paving block.

Secara matematis besarnya kekuatan tekan suatu bahan :

\section{Kekuatan tekan : $\mathrm{P}=\frac{F}{A}$}

Fmaks adalah gaya tekan maksimum ( $\mathrm{N}$ ) yang menyebabkan beban hancur

$\mathrm{F}=\mathrm{m} \times \mathrm{g}$
$A=$ luas penampang $\left(\mathrm{m}^{2}\right)$

$\mathrm{m}=$ massa benda

\section{Metodologi Penelitian}

Dalam penelitian ini bahan tambahan yang digunakan adalah limbah bata merah. Tujuan penelitian ini adalah untuk mengetahui pengaruh penggunaan limbah bata merah sebagai bahan tambahan sebagian jumlah semen pada campuran spesi/mortar.

\subsection{Benda Uji}

Benda uji yang digunakan untuk daya serap pada penelitian ini berupa paving block berbentuk segienam dengan Diameter $20 \mathrm{~cm}$, dan benda uji untuk kuat tekan berupa kubus $5 \times 5 \mathrm{~cm}$. Digunakan 5 variasi penggunaan limbah bata merah sebagai tambahan semen yaitu paving block dengan kadar limbah bata merah $0 \%, 30 \%, 50 \%, 70 \%, 100 \%$. Tiap variasi penggunaan limbah bata merah akan diuji kuat tekannya pada umur 7 hari.

\subsection{Teknik Pembuatan Paving Block segienam d20}

Masukkan lapis I sebagai warna kepala paving block setebal $2 \mathrm{~mm}$ yang terdiri dari semen dan oker dengan perbandingan 1:1/2. Pada lapis II dalam percobaan 1 dengan perbandingan 1:4, masukkan semen dan pasir dalam keadaan lembab, pada percobaan 2 dengan perbandingan 0,7:0,3:4, masukkan semen, limbah bata merah, dan pasir, 0,5:0,5:4 pada percobaan 3 dan pada percobaan 4 dengan perbandingan 0,3:0,7:4, pada percobaan 5 dengan perbandingan 1:4, masukkan limbah bata merah dan pasir. Pukul adonan dengan potongan papan rata berada dibawahnya. Kemudian buka perlahan-lahan cetakan paving block dengan cara menekan bagian kepal cetakan dengan ibu jari, dan jari lainnya menarik tangkai cetakan paving block. Paving block yang sudah jadi diangkat dengan papan, lalu dijemur 1 hari.

\subsection{Teknik Pembuatan Paving Block berbentuk kubus $5 \times 5 \mathrm{~cm}$}

Campuran yang digunakan pada percobaan 1 yaitu semen + pasir (hasil ayakan) dengan perbandingan 1:4, pada percobaan 2 yaitu semen, limbah bata merah dan pasir dengan perbandingan 0,7:0,3:4, pada percobaan 3 dengan perbandingan 0,5:0,5:4, pada percobaan 4 dengan perbandingan 0,3:0,7:4, dan pada percobaan 5 yaitu limbah bata merah 
dan pasir dengan perbandingan 1:4. Kemudian ambil air secukupnya dan campurkan dan aduk sampai adonan merata seperti membuat mortar. Jika adonan sudah tercampur rata, isi cetakan dengan campuran tersebut, kemudian padatkan adonan dilakukan di atas perancah menggunakan sendok semen dengan cara di tekan hingga padat. Setelah adonan padat, diamkan selama 24 jam. Kemudian buka perlahan-lahan cetakan paving block dengan cara membuka baut yang ada di sekitar cetakan. Setelah itu tarik perlahan cetakan ke arah kiri dan kanan. Paving block yang sudah jadi diangkat dengan papan, lalu dijemur selama 7 hari kemudian diuji kuat tekannya.

\section{Hasil dan Pembahasan \\ 4.1 Hasil Praktikum}

Komposisi bahan pembuatan paving block untuk sample 1 dengan menggunakan semen portland $100 \%$ tanpa bahan campuran limbah bata merah pada lapis I digunakan campuran semen portland 340 gram dan oker 170 gram dan pada lapis II digunakan campuran semen portland 340 gram dan pasir 1360 gram. Untuk sample 2 dengan menggunakan semen portland $70 \%$ dan limbah bata merah 30\% pada lapis I digunakan campuran semen portland 340 gram dan oker 170 gram dan pada lapis II digunakan campuran semen portland 238 gram, limbah bata merah 102 gram dan pasir 1360 gram. Untuk sample 3 dengan menggunakan semen portland 50\% dan limbah bata merah $50 \%$ pada lapis I digunakan campuran semen portland 340 gram dan oker 170 gram dan pada lapis II digunakan campuran semen portland 170 gram, limbah bata merah 170 gram dan pasir 1360 gram. Untuk sample 4 dengan menggunakan semen portland 30\% dan limbah bata merah $70 \%$ pada lapis I digunakan campuran semen portland 340 gram dan oker 170 gram dan pada lapis II digunakan campuran semen portland 102 gram, limbah bata merah 340 gram dan pasir 1360 gram. Untuk sample 5 dengan menggunakan limbah bata merah 100\% dan tanpa campuran. Pada lapis I digunakan campuran semen 340 gram dan oker 170 gram dan pada lapis II digunakan campuran limbah bata merah 340 gram dan pasir 1360 gram. Untuk pengujian daya serap digunakan cetakan berukuran segienam dan pengujian kuat tekan digunakan cetakan ukuran $5 \times 5 \mathrm{~cm}$.

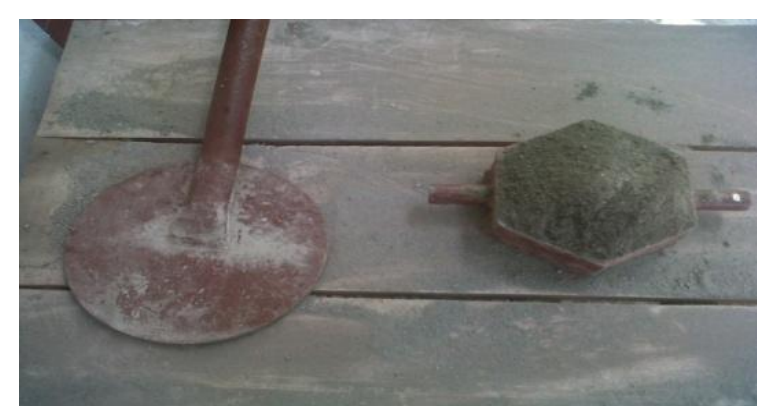

Gambar 1. Kondisi Awal Sebelum Pemukulan

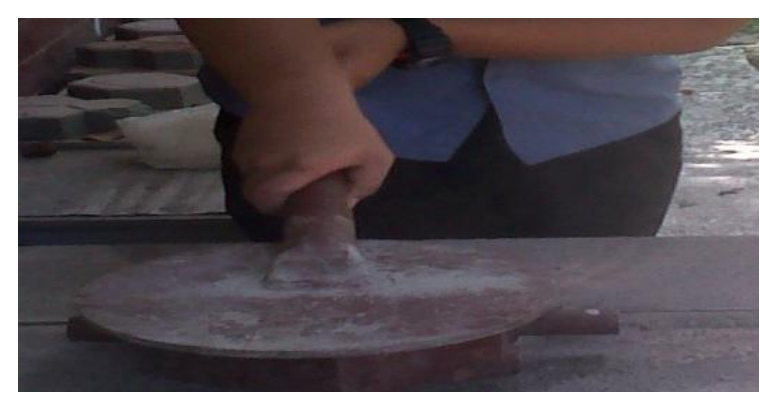

Gambar 2. Pemukulan Pada Benda Uji

\subsection{Perawatan Paving Block}

Setelah benda uji dilepas dari cetakan maka dilakukan perawatan dengan cara dikeringkan selama 7 hari, kemudian disiram merata dan dibiarkan kering dengan suhu udara kamar $\left(20^{0}-25^{\circ} \mathrm{C}\right)$ sampai batas umur 7 hari sesudah pencetakan, paving block siap diuji kuat tekannya. Pengujian benda uji pada penelitian ini hanya dilakukan saat paving block mencapai umur 7 hari.

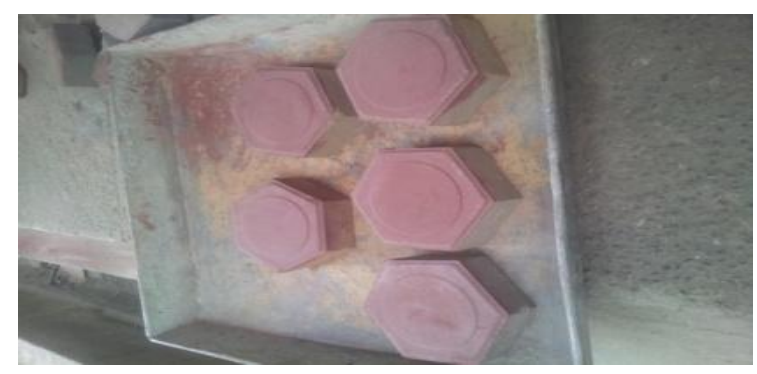

Gambar 3. Perawatan Paving Block

\subsection{Pengujian Daya Serap Paving Block}

Untuk mengetahui besarnya penyerapan air dari paving block yang telah dibuat, maka perlu dilakukan pengujian. Prosedur pengukuran penyerapan air adalah sebagai berikut:

a. Sampel yang telah dibuka dari cetakan diangin-anginkan selama 7 hari dan dilakukan perawatan pada benda uji. 
b. Rendam benda uji dalam air hingga jenuh selama 24 jam, kemudian ditimbang massanya dengan menggunakan neraca digital, disebut massa jenuh.

c. Kemudian keringkan dengan oven selama 24 jam pada suhu $90^{\circ} \mathrm{C}$.

d. Setelah itu, angkat dan timbang massanya dengan menggunakan neraca digital, disebut massa kering.

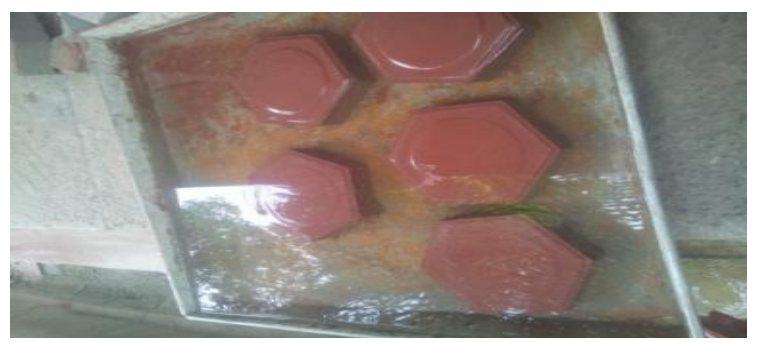

Gambar 4. Perendaman Paving Block

Daya serap pada paving block dalam bentuksegienam, untuk sample 1 dengan menggunakan semen portland $100 \%$ tanpa bahan campuran limbah bata merah, maka didapat timbangan berat basah benda uji 2321 gram,berat kering benda uji 2020 gram, dan didapat nilai penyerapan air sebesar 14,90\%. Untuk sample 2 dengan menggunakan semen portland $70 \%$ dan campuran limbah bata merah $30 \%$, maka didapat timbangan berat basah benda uji 2375 gram,berat kering benda uji 2134 gram, dan didapat nilai penyerapan air sebesar $11,29 \%$. Untuk sample 3 dengan menggunakan semen portland $50 \%$ dan campuran limbah bata merah 50\%, maka didapat timbangan berat basah benda uji 2325 gram, berat kering benda uji 2114 gram, dan didapat nilai penyerapan air sebesar 9,98 \%. Untuk sample 4 dengan menggunakan semen portland $30 \%$ dan campuran limbah bata merah $70 \%$, maka didapat timbangan berat basah benda uji 2101 gram, berat kering benda uji 1642 gram, dan didapat nilai penyerapan air sebesar $27,95 \%$. Untuk sample 5 dengan menggunakan limbah bata merah $100 \%$ tanpa bahan campuran semen portland, maka didapat timbangan berat basah benda uji 2090 gram, berat kering benda uji 1696 gram, dan didapat nilai penyerapan air sebesar $23,23 \%$

Nilai daya serap paving block pada umur 7 hari dengan memiliki variasi komposisi pencampuran bahan yaitu, semen portland $100 \%$ tanpa limbah bata merah nilai serap air 14,90\%. Semen portland $70 \%$ dan limbah bata merah $30 \%$ nilai penyerapan air 11,29\%. Semen portland
$50 \%$ dan limbah bata merah 50\% nilai penyerapan air 9,98 \%. Semen portland 30\% dan limbah bata merah $70 \%$ nilai penyerapan air 27,95\%. Limbah bata merah 100\% tanpa semen portland nilai penyerapan air 23,23. Dari hasil pengujian ini dapat di tentukan bahwa daya serap yang paling tinggi diperoleh apabila menggunakan campuran limbah bata merah $100 \%$.

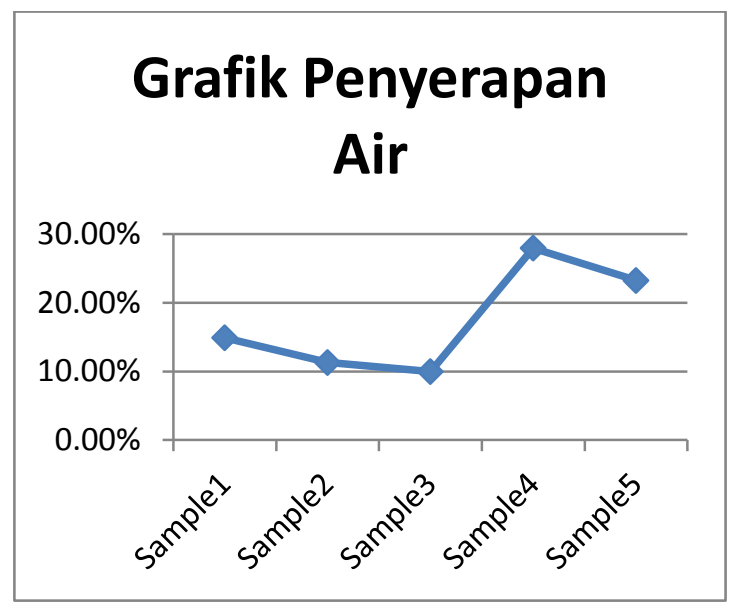

Gambar 5. Grafik Penyerapan Air Paving Block

\subsection{Uji Kuat Tekan Paving Block}

Prosedur Pengujian kuat tekan adalah sebagai berikut:

a. Atur tegangan supply sebesar 40 volt untuk menggerakkan motor penggerak kearah atas maupun bawah. Sebelum pengujian berlangsung, alat ukur (gaya) terlebih dahulu dikalibrasi dengan jarum penunjuk tepat pada angka nol.

b. Kemudian tempatkan sampel tepat berada di tengah pada posisi pemberian gaya dan arahkan switch ON/OFF ke arah $\mathrm{ON}$, maka pembebanan secara otomatis akan bergerak dengan kecepatan konstan sebesar $4 \mathrm{~mm} /$ menit.

c. Apabila sampel telah pecah, arahkan switch kearah OFF maka motor penggerak akan berhenti. Kemudian catat besarnya gaya yang ditampilkan pada panel display, saat beton tersebut rusak.

d. Pengujian kuat tekan ini dilakukan hanya pada waktu paving block berumur 7 hari. 


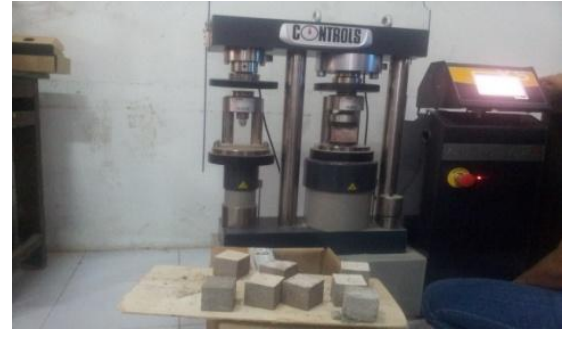

Gambar 6. Pengujian Kuat Tekan Paving Block

Pada paving block yang dikeringkan secara alami 7 hari, untuk sampel no.1 dengan semen portland $100 \%$ dan tanpa bahan campuran limbah bata merah maka ditimbang berat benda seberat 188 gram kemudian diuji kuat tekannya dan didapat nilai kuat tekannya sebesar 1,85 Mpa yang dapat digunakan sebagai tempat parkir kendaraan. Untuk sampel no. 2 dengan semen portland $70 \%$ dan limbah bata merah 30\% maka ditimbang berat benda seberat 186 gram kemudian diuji kuat tekannya dan didapat nilai kuat tekannya sebesar 1,49 Mpa yang dapat digunakan sebagai trotoar. Untuk sampel no. 3 dengan semen portland $50 \%$ dan limbah bata merah $50 \%$ maka ditimbang berat benda seberat 176 gram kemudian diuji kuat tekannya dan didapat nilai kuat tekannya sebesar 1,13 Mpa yang dapat digunakan sebagai taman kota. Untuk sampel no.4 dengan semen portland $70 \%$ dan limbah merah 30\% maka ditimbang berat benda seberat 166 gram kemudian diuji kuat tekannya dan didapat nilai kuat tekannya sebesar 0,60 Mpa, tidak dapat digunakan. Untuk sampel no.5 dengan limbah bata merah $100 \%$ dan tanpa bahan campuran semen portland didapat berat benda sebesar 162 gram namun tidak dapat ditentukan hasil nilai kuat tekannya karena benda uji hancur dalam tahap perawatan. Sehingga dapat disimpulkan bahwa semakin banyaknya campuran limbah bata merah pada pembuatan paving block maka kuat tekannya semakin menurun.

\section{Grafik Kuat Tekan}

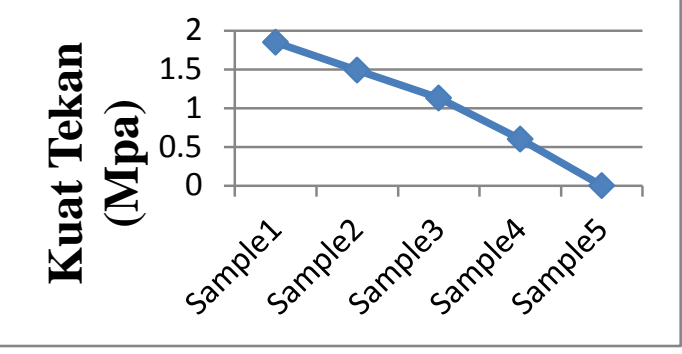

Gambar 7. Grafik Kuat Tekan Paving block

Terlihat bahwa kuat tekan dari paving block yang dikeringkan secara alami selama 7 hari adalah berkisar 1,85 - 0,60 Mpa, paving block yang dibuat dengan komposisi $100 \%$ semen portland dan tanpa bahan campuran limbah bata merah diperoleh nilai kuat tekan 1,85 Mpa. Dan untuk komposisi paving block dengan $70 \%$ semen portland dan 30\% limbah bata merah diperoleh nilai kuat tekan 1,49 Mpa. Untuk komposisi paving block dengan 50\% semen portland dan $50 \%$ limbah bata merah diperoleh nilai kuat tekan 1,13 Mpa. Untuk komposisi paving block dengan 30\% semen portland dan $70 \%$ limbah bata merah diperoleh nilai kuat tekan 0,60 Mpa. Untuk komposisi paving block dengan $100 \%$ limbah bata merah dan tanpa bahan campuran semen portland diperoleh nilai kuat tekan 0 Mpa karena benda uji hancur sewaktu proses perawatan benda uji. Maka klasifikasi jenis bata tersebut termasuk dalam kelas (low density concrete).

\section{Kesimpulan dan Saran}

5.1 Kesimpulan

Dari hasil analisis data dan pembahasan maka diambil kesimpulan, yaitu :

a. Pembuatan Paving block meliputi: Persiapan alat dan bahan/ pengayaan bahan, kemudian bahan baku dicampur dalam wadah kemudian diaduk merata, Penambahan air pada adonan sampai adonan terasa lembab. Untuk mengetahui adonan sudah dapat dipakai, diuji dengan menggambil adonan dengan segegam telapak tangan. Setelah bahan baku menjadi adonan dituang kedalam cetakan, setelah itu dilakukan pemukulan pada cetakan yang berisi adonan untuk memadatkan, kemudian cetakan dibukadan dilakukan perawatan pada 
benda uji. Kemudian dilakukan pengujian yang meliputi penyerapan air dan kuat tekan selama 7 hari.

b. Dari hasil pengujian ini dapat di tentukan bahwa daya serap yang paling tinggi diperoleh apabila menggunakan campuran limbah merah $100 \%$.

c. Semakin banyaknya campuran semen merah pada pembuatan paving block maka kuat tekannya semakin menurun.

d. Limbah bata merah sebagai penganti semen portland dalam pembuatan paving block kurang efektif digunakan karena pada sampel 5 dengan komposisi $100 \%$ semen merah yang dimasukkan dalam benda uji membuat benda uji hancur pada saat diuji kuat tekannya namun memiliki daya serap yang tinggi.

\subsection{Saran}

Berdasarkan kesimpulan diatas maka disarankan beberapa hal sebagai berikut :

a. Sebaiknya diteliti lagi limbah dari bahanbahan yang dapat digunakan sebagai tambahan semen yang memiliki daya serap dan daya dukung yang seimbang untuk pembuatan paving block.

b. Dalam pembuatan paving block, lebih baik limbah bata merah digunakan sebagai bahan tambah dalam pencampuran pasir.

c. Limbah bata merah sebaiknya digunakan untuk pembuatan vas, periuk, dan alat-alat perlengkapan lain yang berbahan dasar tanah liat.

\section{Daftar Pustaka}

Anonim, 1990. Tata Cara Pembuatan Rencana Campuran Beton Normal (SK SNI T 151990-03), Departemen

Pekerjaan Umum

Asmirawaty, Arifuddin. Pages Semen Merah 340560289390722, https://idid.facebook.com 20 Mei 201517.00

Dangzt, iman. 2014 (http://civilkitau.blogspot.com/2014/03 /komposisi semen portland dan fungsinya.html) 20 Mei 2015 16.53.

DEPARTEMEN PU.,1989, SNI 03-0349-1989, Bata beton untuk pasangan dinding, Balitbang, Jakarta
Dharmawansyah, A dan Kurniawan, A, 2007, Penelitian Pemanfaatan Endapan Sampah sebagai Substitusi Agregat Halus dalam Pembuatan Paving Block, Tugas akhir, Universitas Diponegoro, Semarang.

Elrumi, 2012. Paving Block Material. (http://paving-

blok.blogspot.com/2012/11/11/defenisipaving-block.html?m=1) 03/05/2015 19.25

Hidayat, Taufik. Semen Merah Terhadap Kuat Tarik Langsung Mortar Semen Merah Kapur Pasir http://sipil.ub.ac.id 20 Mei 2015 16.31

Kusuma, Dwi, 2012. Beton Non Pasir. (http://kuat-tekan-pavingblock.com) 03/05/2015 20.01

Mulyono, Tri. 2004. Teknologi Beton. Yogyakarta: Penerbit Andi

Pamungkas, 2007. Metode Konvensional Paving Block,.Semarang.

Sebayang, 2005. Teknologi Beton. Bandar Lampung. Universitas Lampung.

Tjokrodimuljo, K. 1996. Teknologi Beton. Buku Ajar, Jurusan Teknik Sipil, Fakultas Teknik,Universitas Gajah Mada. 